\title{
DYNAMICS OF GROUP COMMUNICATION IN ARISAN'S ACTIVITIES
}

\author{
Oleh: \\ Tang Natasha ${ }^{1}$ \\ lle ne ${ }^{2}$ \\ Siti Me isyaroh ${ }^{3}$
}

\begin{abstract}
This study observed urban lifestyle phenomenon in Jakarta, namely arisan. Conducted in the outskirt of Jakarta, which is Kelapa Gading. This study, which aimed to observe the phenomenon of life style through arisan activities, attempted to observe ideas that underlies the motives of individuals when participating in arisan group and when consuming goods in their daily life. The study found that identity was important in arisan. It emerged as arisan activities were dominated by consumption. Competition among the members of arisan group occurred as a result. It showed who had higher identity and who had not. The role of the leader of the group was interesting as well. The leader was succesful to persuade the members to follow her orders for the sake of arisan activity. The power of the leader was not realized by other members. Strong bond of friendship between the leader and the members made them entering a system where one controlled others on what needs to be controlled.
\end{abstract}

Keywords: Consumerism, Arisan, Identity, Group Communication.

\begin{abstract}
ABSTRAK
Studi ini bermaksud mengkaji fenomena gaya hidup di masyarakat perkotaan, khususnya wilayah Jakarta melalui kegiatan arisan. Penelitian dilakukan di daerah Jakarta Utara, tepatnya di daerah Kelapa Gading. Berdasarkan penelitian yang dilakukan, ditemukan bahwa identitas merupakan hal yang penting di dalam kegiatan arisan. Identitas kemudian muncul karena kegiatan arisan yang ada didominasi oleh pola-pola konsumsi di dalamnya. Dari kegiatan konsumsi itu, lahirlah sebuah kompetisi antar anggotanya untuk menunjukkan siapa yang memiliki identitas lebih tinggi dan siapa yang tidak. Sang ketua arisan memunyai pengaruh besar dalam memengaruhi para anggotanya untuk mengikuti segala perintahnya dengan dalih kepentingan kegiatan arisan. Kekuatan ini tidak disadari oleh para anggota. Jalinan pertemanan yang kuat antara sang ketua dan anggotanya yang lain, membuat mereka masuk ke dalam sebuah sistem di mana ada yang mengendalikan dan apa yang dikendalikan.
\end{abstract}

\section{Kata kunci: Konsume ris me, Arisan, Identitas. Komunikasi Kelompok}

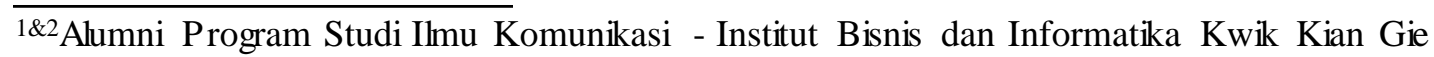

${ }^{3}$ Alamat kini: Institut Bisnis dan Informatika Kwik Kian Gie, Jh Yos Sudarso Kav. 87 Sunter, Jakarta 14350 Penulis untuk Korespondensi: Telp. (021) 65307062 Ext. $705 . \quad$ E-mail: siti.meisyaroh@Kwikkiangie.ac.id.

Program Studi Imu Komunikasi - Institut Bisnis dan Informatika Kwik Kian Gie 


\section{INTRODUCTION}

Arisan is part of the activities of some groups of Indonesian society, especially women. Arisan is a term used to simplify a concept regarding a financial regulatory system especially in Indonesia. According to Kern (1986 in Hospes, 1992: 371), the Rotatting Saving and Credit Association (ROSCA) or what is known as arisan is an attractive format as a financial institution in rural areas.

Arisan is a regulatory system because it contains rules for its members. The regulation then becomes a system that regulates all activities related to money managed in it. Hospes (1992: 373) explains that in the past, arisan was one of the means for villagers to save. How ever, this is deemed inefficient because people have to become members first to be able to save in it.

This arisan is still just a simple financial institution based on mutual trust. Eibel and Marx (1987, in Hospes, 1992: 373) state that arisan is not strong enough to become an agent of development so that it will remain an informal financial institution that tends to be static and does not affect development in a country.

Arisan has now changed with the times. Judging from its type, now adays arisan is not only in the form of money as in general, but it can also use gold or other luxury items. Then, when viewed from the activities, currently the arisan participants are carried out from one place to another. Place choices are usually based on comfort considerations.

Various places that are usually chosen to do social gathering activities include a cafe, mall or a hotel lounge. This is one of the attractions of arisan for researchers. Researchers see arisan as an opportunity to see the dynamics of middleclass identity in Indonesia. In the North Jakarta area, precisely in Kelapa Gading, there is an arisan group consisting of 16 young mothers.
They named their arisan group "Tiger Cattle" which means beautiful mother anther child. Their economic condition is stable and sufficient, making this arisan activity attractive because it is dominated by activities carried out outside the home and requires a lot of money.

In the "Animal Tiger" group, arisan is not the main activity. However, this arisan activity is always followed by other activities such as eating at expensive restaurants or cafes, shopping, or just taking a walk in the shopping center. The members of this arisan prepare the concept carefully when they are about to carry out the arisan, for example, every time they do the arisan activity, the members will make an appointment to wear the same color of clothes. "Animal Tiger" itself was founded in 2012. Until now, "Tiger Livestock" has a number of members of 16 people.

They regularly meet every month, even outside the social gathering, they also often meet just to hang out. This means that from 2012, they did not stop holding social gathering activities. If it runs out on the last social gathering shake which is 16 , they will start over from the beginning and so on. Thus, it has been around 7 years since the "Tiger Livestock" arisan group was founded and met regularly every month. The fee for the arisan is Rp. 2,000,000 and is shaken at the beginning of the month. Tariff Rp. 2,000,000 is only valid this one year. Previously, the fee was Rp. 1,500,000.

The number of contributions is quite large because most of the members get money from their husbands, where they are mostly housewives. "Animal Tiger" is just one more extraordinary development of the term arisan. Arisan which is usually held within the scope of the neighborhood or the scope of the RT or RW such as PKK activities can still be found. 


\section{LITERATURE REVIEW}

However, the problem in this research is how the development of arisan from what was originally a rotational savings account to become a modern lifestyle among the middle class with a large supply. In social science, a lifestyle (life style) is a way of how a person lives.

According to Assael (1984), lifestyle is "A mode of living that is identified by how people spend their time (activities), what they consider important in their environment (interest), and what they think of themselves and the world around them (opinions)". It can be concluded that a lifestyle is how a person lives, spends his money after his primary needs are met, as well as how someone allocates their free time.

Erving Goffman in The Presentation of Self in Everyday Life (1959: 40) argues that social life mainly consists of ritualized theatrical appearances. Humans act as actors who are playing a play on a stage where the social environment around them has a role as an audience, either directly or indirectly when they see the show. In this connection, everything that is done and attached to him is what is displayed in front of everyone. Furthermore, various interpretations of what a person wears and what he consumes.

In a capitalist society, the activity of consuming goods as part of a lifestyle is stimulated for temporary purposes. According to Anthony Giddens (1991: 198), the project of human identity is then translated into the project of owning the desired goods and the pursuit of an artificially framed lifestyle. According to Chua Beng Huat (2000: 18), in Asia the form of consumption has become different, especially after the 1997 recession.

According to Chua, post 1997, the symbolic value of consumption has become important in Asia. "The need to 'maintain' a lifestyle is all the more necessary for one of the newly rich to communicate to the world that is falling apart around him/her that he/she remains 'unaffected' and continues to be doing well economically, in hope of retaining the confidence of colleagues and business associates".

Huat (2000: 2) also states that daily rituals have transformed into a different lifestyle with the consumption of goods or services which can be seen as the emergence of 'new rich people' in Asia, a group composed of a new class of business people and the emergence of a professional middle class. and bureaucrats. In Indonesia, according to Solvay Gerke (in Chua. 2000: 135), the symbolic demonstration of classes and groups in the lifestyle was formed as an effort to demonopolize the hierarchy that was once dominated by Javanese court culture and by the Neo-Priyayi group of employees before the New Order regime.

According to GerkeBenih, the middle class in Indonesia had emerged when the colonial government was in Indonesia. Another view on the middle class for example is the middle class in Islam in Heffner (1993 in Indonesia, Vol. 56 (October 1993) pp 135). The emergence of NeoPriyayi began when a group of indigenous people who worked in the colonial government served as officials. So that, at the end of the colonial period, they automatically occupied government positions and were considered to have influence in society and became a new group, namely the Neo-Priyayi who later transformed into the middle class.

Heryanto (in Pinches, 1999: 160) argues that the rich class is dominated by 'Westerners' and 'ethnic Chinese' (Chinese), if anything that can be added is the upperclass government employees, although dominati on of the Kraton Jawa class and Neo-Priyayi.

Based on the background described above, the focus of this research is (1) what are the forms and practices of consumption in 
"Animal Tiger" in every activity they do so that it becomes a lifestyle for each member? and (2) how is the dynamics of the power relations of the arisan leader in "Tiger Livestock" in their activities?

Blakely and Synder (1997 as quoted by Farida, 2008: 28) explain that the Gated Communi ty is part of suburbanization. A fenced community or better known as the Gated Community can also be an entry point when we want to study lifestyle, especially urban communities. This trend arises when the city center has lost its position as the 'strongest' place in the metropolis hierarchy.

\section{FINDING \& DISCUSSION}

Kelapa Gading has experienced tremendous infrastructure development in this region. Gated Community grows as a result of urban development. The condition of the city which is increasingly unfriendly to the dense development centered in the city, has made some people move their homes to sub-urban areas which have the potential as better living areas.

More than half of the "Tiger Livestock" members live in a residential area in Kelapa Gading. They are also mothers who have children who attend international standard schools and can be considered as a Gated Community group. Tessa, who is the head of the "Tiger Livestock" arisan group, is the parent of the students who initiated the "Tiger Livestock" arisan for housewives who initially took their children to school and unti 1 now these children have occupied elementary schools in Sower.

Fenced communities in Indonesia are inhabited by those who do not represent the wealthy class alone. They also come from the "working middle class" who have a consumptive tendency and a luxurious lifestyle. An exclusive impression is attached to the identity of the residents of the fenced community, including the members of "Tiger Livestock".

Blakely and Snyder (2003, quoted by Widhyharto, 2009: 205) explain that the emergence of the Gated Community, especially in Indonesia, actually gave birth to urban fragmentation. Tessa and her friends who come from the upper middle class, in the end, only build intimacy with a group of young mothers who deliver children with economic conditions that are not much different. Their children's school is a reflection of the culture, race, class and identity of the arisan members. Tessa, who is married to an architectural firm entrepreneur, would love to send her child there.

For women who are married and become mothers, women are not only responsible for children who are born well, but also that they are responsible to their younger families, both in terms of age and the generation under them (Nihof, 1998: 245).

Djajadiningrat and Nieuwenhui s (1992 in Nihof, 1998: 245) states that women who are part of the Javanese elite family, a mother is also required to maintain family dignity. It is important to maintain good manners and manners so that social relations and kinship with other elite families is maintained.

Nihof (1998: 246) also says that for a mother who is in a lower economic condition, the role of the mother at that time is limited to being a good mother by taking good care of their children too. The role of mothers began to move up to the local level of the village where they lived through an activity called PKK (Family Welfare Development).

In PKK activities, women will be asked to take part in activities deemed to be efforts to develop the area. Mothers were asked to volunteer to take part in PKK activities, which actually made them lose time to take care of their families, especially their children. PKK becomes an arena for 
them to leave their house and interact with their social environment.

PKK is also one of the emergence of arisan activities. The arisan agenda is sometimes still included in the PKK activities. The feeling of mutual cooperation is still inherent in previous arisan activities. For example, when a family member of the arisan member is sick, the arisan members will set aside the little money they have to help.

Simplicity is no longer visible in most social gathering activities today. Arisan is no longer a gathering place, but as an arena or arena for the formation of meaning and class. Consumption patterns and practices are becoming more dominant in today's arisan activities. According to Geertz (1962), who examined Modjokuto in the 1950s, he realized that the forms of arisan would change according to changes in the structure of society.

Lifestyle develops in society which is defined by material objects which become the benchmarks for social class. Arisan is no longer seen as merely fulfilling the necessities of life for socializing as believed by Geertz (1962), nor is it merely an economic instrument for saving as explained by Papanek and Schweede (1988), but it has also been related to socio-cultural aspects.

The consumption contained in arisan activities is related to one's taste, identity, and lifestyle. Fashion cycle has become a necessity in arisan activities. Each arisan participant competes to use the best fashion products during the arisan activity. These arisan members share the same fashion knowledge, which is fashionable, up to date, and glamorous.

According to Baudrillard (2009: 13), this is an analysis principle of consumption, namely when the consumer's mentality is individual and collective. This is in accordance with the existence of human beings, namely as individual and collective creatures. The basis for consideration in consumption is the nature of consumers who are social creatures.

Lifestyle, not only talking about the size of one's income in everyday life, but is a person's choice of a product to someone's desire to consume a product. This cannot be separated from the problem of structured social perception and habitus. Therefore, the social differences that occur and take place in society are not only caused by differences in social class contained in it, but are also formed by how a person lives or by habitus.

According to Bourdieu (1986 in Paterson, 1997: 44), habitus is a system in which a person is surrounded by desires, desires, and choices about how they live according to the social constructs that exist in their environment. Habitus is formed by a long social process in it. Construction occurs in society over and over again so that it becomes one truth which eventually becomes a habit in society.

The important thing in the formation of habitus in one community group is a structure. The structure that has been formed then becomes a habitus, and is followed by the community as a pattern in everyday life. The existence of an agent is also an actor who forms a habitus. Bordieu uses the concept of habitus to understand the structure and agent and who is behind them, which is then able to lead a group of people to understand it as a truth.

Arisan is an alternative activity for someone to fill their spare time. Therefore, social gathering and leisure are related. Leisure can be interpreted as a form of outlet for pleasure / fun. So, leisure is defined as the ability of people to consume goods or things related to consumption practices to fill their available free time.

Everyone who takes part in the arisan is required to have a lot of free time. This is 
because in arisan activities, it requires and takes a long time. The average time spent is around 3-5 hours in each arisan activity, even more than the average.

Money, consumption, and having fun are various things that exist in social gathering activities. This is because these consumption practices form a unity and occur repeatedly regularly which then must be followed by everyone who participates in the activity if they do not want to be described as different by other members of the arisan group. Generally, arisan activities are carried out every 1-2 times a month, depending on the agreement.

Everyone in the arisan group has almost the same consumption pattern during that time. Themes, locations, uniforms, make up styles, similar accessories are some things that are almost always present in every social gathering activity. Fashion is something that has become synonymous with this activity. An arisan leader who is in control to determine these various things. The head of the arisan has a role to always follow fashion developments which are then applied in the arisan and followed by all its members.

The chairman of every arisan activity always has someone who has power. Control and control are the keywords of the role of the chairman. The chairman can control all arisan activities according to what he has conceptualized and can control all members to follow instructions regarding themes, clothes, accessories to locations according to Tessa's wishes. It can be said that Tessa is a person who has more power in the management structure of "Tiger Livestock" than other members. He will delegate tasks and make decisions so that the monthly arisan activities run well, for example, such as assigning an assignment to one of the members to make a booking for a place where the arisan activity is held.
As time went by, the intensity of their frequent meetings made that power slowly grow and strengthen in the "Animal Tiger" circle. This is what is known as soft power. Chua Beng Huat (2012: 119) says that before understanding soft power, it is necessary to first understand the meaning of power which then affects the perception of soft power itself.

In Weberian's view, power is the ability to influence someone to do what he wants. Although it is not certain that what is done is what the subject who is given the order likes. Chua uses the concept of soft power to find out how products in the form of drama, music and fashion products originating from Japan, China and Korea affect the world, especially Indonesia.

Initially, soft power was seen in the context of a state where the state through political parties was able to influence the ideology of its citizens in order to gain support and power in leading a country. This concept was developed by Joseph Nye, an American political observer whose concept is one of Chua's references in using the concept of soft power (2000: 119).

The arisan conducted by the "Animal Tiger" group is different because of the consumption patterns in it. Arisan with a simple scheme carried out by mothers in the village or in the scope of the RT still exists today, but the presence of "Animal Tiger" is its own color, especially if you want to study lifestyle studies. The pattern that exists in "Animal Tiger" activities eventually becomes part of their daily lives even though they are not currently gathering as members of "Tiger Livestock".

Lifestyle is formed due to collective tastes that are awakened in the activities of "Animal Tiger" which are then carried away in daily life and become habitus. They keep this taste in choosing material objects to maintain their identity as the upper middle 
class in the social space around them. "Animal Tiger" is a system built from the Gated Community.

Tessa and her friends who live in almost the same area plus their children's school environment make social gathering activities even more colorful. Departing from the location of their homes which are mostly the same, but it is precisely where their children go to school that makes their relationship even closer. Because their children attend the same school and schools are expensive, it can be said that their economic abilities are equal.

It is this equality that builds a comfortable atmosphere for anyone in it so that they feel they have to go back to adapting to people outside their group, because what they discussed in the arisan activity, one of which was discussing their children's activities at school. Equality is what makes their relationship even closer.

Tessa as the head of the "Animal Tiger" group has a tremendous influence on the dynamics of "Animal Tiger" activities. Tessa's great influence has succeeded in producing policies that apply to the "Animal Tigers" and then approved and obeyed by all other members.

Through its policy, "Animal Tiger" then becomes a system in which there is control and some are controlled. They seem to come out of the system in domestic life and feel free because they can express themselves through activities they like. Without them knowing it, by joining the "Animal Tiger" where Tessa served as chairman, they entered another system called arisan where they had to follow the patterns and policies set out in the arisan activity. The system that was built and the policies that were created were not realized by the other members. The emotional relationship that is built up because of longstanding friendships makes Tessa's power last.

\section{CONCLUSION}

Research on the development of social gathering as a lifestyle. There are two main questions in this research, namely the development of arisan as a lifestyle and the power relations that grow in arisan groups. The study was conducted on the "Animal Tiger" group. The results showed that the arisan activity which initially grew in a small, limited environment in the PKK environment with social values and mutual cooperation, turned into an inherent lifestyle.

Arisan is no longer a place to gather to stay in touch in a limited environment with installments that are adjusted to the lowest ability of its members, but it has turned into a lifestyle where fashion, consumption, and the presentation of the upper middle class are also developing. In addition, in today's arisan groups, power relations can grow and be well established. The chairperson is an individual capable of controlling group members, where the power is received without slowly, but surely and strongly due to soft power.

\section{REFERENCES}

\section{Books}

Assael, H. (1998), Consumer Behavior and Marketing Action, 6th edition. New York: International Thomson Publishing.

Barker, Chris (2004), The Sage Dictionary of Cultural Studies. London: Sage Publications.

Baudrillard, Jean (1998), The Consumer Society. London: Sage Publications.

Chua, Beng Huat (2012), Structure, Audience and Soft Power in East Asian Pop Culture, Hongkong: University Press.

Chua, Beng Huat (2000), Consumption in Asia, Lifestyle and Identities. London and New York: 
Routledge.

Cresswell, John (2003), Research

Design: Qualitative and Mixed

Approaches. Sage Publication.

Fromm, Erich (2005), On Being Human,

New York dan London:

Routlledge.

Giddens, Anthony (1991), Modernity and Self-Identity: Self and Society in the Late Modern Age, California: Stanford University Press.

Goffman, Erving (1959), Presentation of Self in Everyday Life, New York: Doubleday Anchor Books.

Heryanto, Ariel (ed). (2012), Budaya Populer Di Indonesia Mencairnya Identitas Pasca Orde Baru (terj), Yogyakarta: Jalasutra Yogyakarta.

Paterson, Mark (2006), Consumption and Everyday Life. New York: Routledge.

Pinches, Michael (1999), Culture and Privilege in Capitalist Asia. London and New York: Routledge

The sis

Asiz, Rangi Faridha (2008), Thesis:

Fenomena Gated Community di Perkotaan. Universitas Indonesia.

Nova, Setyaningrum (2012), Thesis:

Perempuan dan Keperempuanan: Analisis Posfeminisme Terhadap Celebrity Shopper dan

Confessions of a Shopaholic, Universitas Gadjah Mada.

Youn-Mee, Cho (1997), Thesis: Gaya

Hidup dan Budaya Konsumen:

Kasus Konsumen Galeria di

Yogyakarta, Universitas Gadjah

Mada.
Ekonomi Indonesia 2015 Capai 5,2 Persen 2015. https://w w w .ugmac.id/id/berita/9598 bank.dunia.prediksikan.pertumbuha $\mathrm{n}$. ekonomi.indonesia.2015.capai.52.per sen . Diakses pada 2 Januari 2019.

\section{Journal}

Geert, Clifford (1962), The Rotating Credit Association: A "Middle Rung" in Development. The Journal of Anthropology. Vol. 45, No. 3 (Nov 2006).

Hospes, Otto. 1992 "People That Count:

The Forgotten Faces of Rotating Saving and Credit Associations In Indonesia". The Journal of Anthropology. Vol. 16. No. 4. PP 371-441.

Niehof, Anke. 1998 "The Changing Lives of Indonesian Woman Contained Emancipation under Pressure”. The Journal of Anthropogy. Vol. 154, No. 2. PP. 236-258.

Widhyharto, Derajat S. (2009)

"Komunitas Berpagar; Antara Inovasi Sosial dan Ketegangan Sosial ". Jurnal Ilmu Sosial dan Politik. Vol. 13. No. 2. (204230). Universitas Gadjah Mada.

Woodward, Kathryn (ed.). 2002. Identity and Difference. London: SAGE Publications.

Yulius, Hendri. 2019. C*BUL: Perbincangan Serius tentang Seksualitas Kontemporer. Tangerang Selatan: Marjin Kiri.

\section{Inte me t}

Bank Dunia Prediksikan Pertumbuhan 